\title{
Perbadingan Metode Weight Product dan Vikor Dalam Menentukan Siswa Berprestasi
}

\author{
Nurhadi $^{1}$, Kejus Ronatal Sinaga ${ }^{2}$, Maulana Yusuf ${ }^{3}$, Rachmat Hidayat ${ }^{4}$, Yusnia Budiarti ${ }^{5}$ \\ ${ }^{123}$ Sistem Informasi, STMIK Nusa Mandiri \\ ${ }^{4}$ Sistem Informasi, Universitas Bina Sarana Informatika \\ ${ }^{5}$ Teknik Informatika, STMIK Nusa Mandiri \\ 1nhadi187@gmail.com , 2sinagakejus71@gmail.com , ${ }^{3 k}$ hususstudy12@gmail.com , \\ 4rachmat.rch@bsi.ac.id , 5 yusnia.ybi@nusamandiri.ac.id
}

\begin{abstract}
At Maadrasah Ibtidaiyah Jamiatul Gulami Tangerang, he often selects outstanding students as a form of spurring the potential to be competitively healthy. But often the process carried out by the Madrasah experiences a calculation error. For this reason, the authors provide a solution, namely the SPK process to determine outstanding students at madrasah ibtidaiyah jamiatul gulami Tangerang. In decision support systems, there are several methods, including those used in this study, namely WP and VIKOR. The Weight Product (WP) method is a method that uses the multiplication of values, attributes to connect ratings, by first ranking each attribute. Meanwhile, the Vise Criterion method, Jumske Optimizakija I Kompromineso Resenje (VIKOR) ranks alternatives and determines solutions that are close to ideal. In the research, data collection techniques were carried out by observing the location of the research and conducting interviews with a teacher named Muhamad Syakir S.Ag at the Madrasah. The results obtained from the research that has been done, namely the WP method are shown to A1 on behalf of Amelia Putri with a value of 0.104, while in the VIKOR method it is shown to A5 on behalf of Eka Yulia with a value of 1.00 .
\end{abstract}

\section{Keywords: SPK Student Achievement WP, Vikor}

Abstrak: Pada Maadrasah Ibtidaiyah Jamiatul Gulami Tangerang seingkali mengadakan pemilihan siswa berprestasi sebagai bentuk memacu potensi untuk berkompetitif secara sehat. Tetapi seringkali proses dilakukan oleh Madrasah tersebut mengalami kekeliruan perhitungan. Untuk itu penulis memberikan solusi yaitu dengan proses SPK untuk menentukan siswa berprestasi pada madrasah ibtidaiyah jamiatul gulami Tangerang. Pada sistem penunjang keputusan terdapat beberapa metode diantaranya yang digunakan pada penelitian ini yaitu WP dan VIKOR. Metode Weight Product (WP) adalah metode yang menggunakan cara perkalian nilai, atribut untuk menghubungkan rating, dengan dilakukan dipangkatkan terlebih dahulu rating pada setiap atribut. Sedangkan Metode Vise Kriteriajumske Optimizakija I Kompromineso Resenje (VIKOR) melakukan perangkingan terhadap alternatif dan menentukan solusi yang mendekati ideal. Pada penelitian dilakukan teknik pengumpulan data dengan cara observasi ketempat lokasi yang menjadi penelitian dan melakukan wawancara kepada seorang guru bernama Muhamad Syakir S.Ag di Madrasah Tersebut. Pada hasil yang diperoleh dari penelitian yang telah dilakukan yaitu dengan Metode WP ditunjukan kepada A1 atas Nama Amelia Putri dengan nilai 0.104.Sedangkan pada metode VIKOR ditunjukan kepada A5 atas nama Eka Yulia dengan nilai 1.00 .

Kata kunci: SPK Siswa Berprestasi WP, Vikor

(1)(9) This is an open access article distributed under the Creative Commons Attribution License, which permits unrestricted use, distribution, and reproduction in any medium, provided the original work is properly cited. O2019 by author and IJSE-Indonesian Journal on Software Engineering.

\section{A. PENDAHULUAN}

Prestasi belajar merupakan sebagai ukuran pencapaian dari usaha yang dilakukan siswa dalam keterampilan, penguasaan materi, maupun pengetahuan yang ditunjukan dalam bentuk nilai. (Noviyanti \& Rizki, 2019) Madrasah Ibtidaiyah Jamiatul Gulami merupakan salah satu 
madrasah di tangerang, yang terletak di gondrong seberang. Banyak sekali para siswa yang menempuh pendidikan dasar nya di madrasah ibtidaiyah Jamiatul Gulami. Mereka juga banyak memiliki potensi kemampuan yang berbeda-beda. Pengetahuan dan kemampuan tersebut dapat terus berkembang seiring berjalan nya waktu. Menjadi siswa berprestasi adalah sebuah impian dari seluruh siswa yang ada di madrasah ibtidaiyah Jamiatul Gulami.

Untuk itu Madrasah Ibtidaiyah Jamiatul Gulami setiap semester nya selalu mengadakan pemilihan siswa berprestasi. Sebagai bentuk untuk memacu potensi siswa untuk berkembang secara kompetitif yang sehat. Tetapi seringkali pemilihan yang dilakukan oleh Madrasah Ibtidaiyah Jamiatul Gulami mengalami kekeliruan dikarenakan data yang digunakan tidak sesuai dan relevan terhadap penilaian untuk setiap siswa nya.Seharus nya yang dilakukan oleh Madrasah Ibtidaiyah Jamiatul Gulami melakukan seleksi berdasarkan akademik maupun non akademik. Serta perlu didukung dengan menggunakan sebuah sistem yang handal untuk dapat menyeleksi siwa berprestasi dengan hitungan yang tepat. Untuk itu dalam melakukan perhitungan ini, metode yang digunakan adalah Weight Product dan Vikor.

Adapun kelebihan dan kekurangan dari metode Weighted Product (WP) dan Vise Kriteriajumska Optimizicija I Kompromisno Resenje (VIKOR) ini yaitu Kelebihan Metode WP. Mempercepat proses perhitungan nilai kriteria dan perangkingan untuk setiap alternatif. Mempermudah pengguna untuk memberikan pembobotan terhadap kriteria yang memiliki nilai yang hampir sama. Dapat digunakan untuk pengambilan keputusan single dan keputusan multidimensional. Metode ini digunakan untuk menyelesaikan pengambilan keputusan secara praktis, karena konsepnya sederhana dan mudah dipahami.(Janosik, 2005)

Sedangkan Kelebihan metode vikor yaitu Mempunyai nilai lebih mendekati solusi ideal dengan menggunakan cara linear.(Fauzi et al., 2020).Metode WP (Weight Product) adalah metode yang dapat digunakan sebagai cara penyelesaian masalah MADM (Multi Attribute Decision Making). Pada metode WP untuk menghubungkan nilai atribut mengggunakan cara perkalian, dilakukan dengan nilai atribut dipangkatkan terlebih dahulu dengan bobot atribut yang bersangkutan Metode Vikor ( Vise Kriteriajumska Optimizicija I Kompromisno Resenje ) dalam bahasa Serbia, yang artinya Multicriteria Optimization dan Compromise Solution adalah metode perangkingan dengan menggunakan indeks peringkat multikriteria berdasarkan ukuran tertentu dari kedekatan dengan solusi yang ideal.(Limbong \& Dkk, 2020)

Pada penelitian yang dilakukan dalam penentuan murid berprestasi di Madrasah Ibtidaiyah Jamiatul Gulami penulis mempunyai tujuan yaitu : Mengolah SPK sebagai alternaif dalam pemilihan siswa berprestasi pada Madrasah Ibtidaiyah Jamiatul Gulami Tangerang. Menerapkan metode Weight Product dan Vikor sebagai sistem pendukung keputusan penentuan siswa berprestasi. Memberikan kemudahan dalam melakukan pemilihan siswa yang berprestasi. Meminimalkan waktu dalam menentukan siswa yang berprestasi.

\section{B. TINJAUAN PUSTAKA}

Sistem Penunjang Keputusan (SPK) Konsep Sistem Penunjang Keputusan (SPK) diperkenalkan pertama kali oleh Michael S. Scoott Morton pada tahun 1970-an dengan istilah Management Decision System. Definisi system adalah sekumpulan hal atau kegiatan atau elemen atau subsistem yang saling bekerja sama atau yang dihubungkan dengan cara-cara tertentu sehingga membentuk satu kesatuan untuk melaksanakan suatu fungsi guna mencapai suatu tujuan.(Ayu Septiana Sari, Jumadil Nangi, 2016)

Sistem Pendukung Keputusan merupakan system informasi interaktif yang menyediakan informasi, pemodelan, dan pemanipulasian data. Sistem ini digunakan untuk membantu pengambilan keputusan dalam situasi yang semiterstruktur dan situasi yang tidak terstruktur, dimana tidak seorang pun tahu secara pasti bagaimana keputusan seharusnya dibuat. (Muslihudin \& Rahayu, 2018)

Metode Weight Product (WP) merupakan salah satu metode yang sederhana dengan perkalian untuk menghubungkan rating atribut dimana setiap atribut harus dipangkatkan dengan bobot atribut yang bersangkutan.(Yusnaeni, 2018) Hal tersebut dinamakan normalisasi.

Metode Vikor ( Vise Kriteriajumska Optimizicija I Kompromisno Resenje ) adalah salah satu metode pengambilan keputusan multi kriteria atau yang lebih dikenal dengan istilah Multi Criteria Decision Making (MCDM). MCDM digunakan untuk menyelesaikan permasalahan dengan kriteria yang bertentangan dan tidak sepadan. Metode ini berfokus pada peringkat dan pemiliahn dari sekumpulan alternatif kriteria yang saling bertentangan untuk dapat mengambil keputusan 
untuk mencapai keputusan akhir. VIKOR melakukan perangkingan terhadap alternatif dan menentukan solusi yang mendekati kompromi ideal (Wijaya, 2019).

\section{METODE PENELITIAN}

Penelitian merupakan kegiatan untuk memecahkan berbagai persoalan yang ada disekitar kita, sekaligus sebagai motor penggerak yang menghasilkan ilmu pengetahuan. Melalui buku ini kita dapat memahami bagaimana sebuah prosedur penelitian mulai dari penentuan masalah, pelaksanaan sampai dengan pelaporannya, sehingga sangat komprehensif sebagai referensi penelitian yang menggunakan pendekatan kuantitatif. Semoga dapat memberikan acuan bagi semua dalam proses dan pelaksanaan kegiatan penelitian.(Suryani \& Hendryadi, 2015)

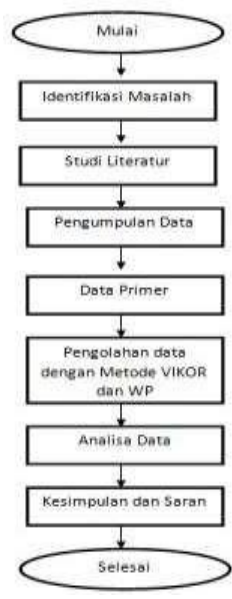

\section{Gambar 1.Tahapan Penelitian}

Pada gambar diatas menjelaskan beberapa tahapan - tahapan penelitian yang dilakukan oleh kami dimulai dari indentifikasi masalah yang terkait dengan penelitian kami. Setelah melakukan identifikasi masalah kami menentukan metode yang akan digunakan oleh kami melalui studi literatur. Pada tahap selanjutnya kami melakukan pengumpulan data yang diproses menjadi data primer untuk melakukan pengolahan data dengan metode VIKOR dan WP. Langkah selanjutnya analisa data dari hasil yang telah dikelola melalui metode yang digunakan untuk mendapatkan kesimpulan dan saran.

Metode Weighted Product menggunakan teknik perkalian untuk menghubungkan rating atribut, dimana rating tiap atribut harus dipangkatkan terlebih dahulu dengan bobot atribut yang bersangkutan. Proses ini sama halnya dengan proses normalisasi. Preferensi untuk alternative Ai diberikan sebagai berikut. (Suryeni et al., 2015) Adapun algoritma penyelesaian dari metode weight product yang sebagai berikut :

1. Proses pertama adalah mencari nilai bobot $\mathrm{W}$

$$
W_{j}=\frac{W_{j}}{\sum W_{j}}(1)
$$

2 Proses ini sama halnya dengan proses normalisasi. Untuk menormalisasikan nilai yang akan digunakan menggunakan rumus

Dimana:

$$
S i=\prod_{j}^{n}=1 X_{i j}^{w j}
$$

$\mathrm{S}=$ Menyatakan preferensi alternative yang dianalogikan sebagai vector $\mathrm{S}$

$\mathrm{X}=$ Menyatakan nilai kriteria

$\mathrm{W}=$ Menyatakan bobot kriteria

$\mathrm{I}=$ Menyatakan alternatif

$\mathrm{J}=$ Menyatakan kriteria 
$\mathrm{N}=$ Menyatakan banyaknya kriteria

3. Dengan $\mathrm{i}=1,2, \ldots, \mathrm{m}$; dimana $\sum \mathrm{wj}=1 \mathrm{wj}$ adalah pangkat bernilai positif untuk atribut keuntungan, dan bernilai negatif untuk atribut biaya. Dan untuk mencari nilai akhir, menggunakan rumus.

Dimana :

$$
V_{i}=\frac{\Pi_{j}^{n}=1 x_{i j} w_{j}}{\Pi_{j}^{n}=1(x j *) w j}(3)
$$

$\mathrm{V}=$ Menyatakan nilai preferensi alternatif dianalogikan sebagai vector $\mathrm{V}$

$\mathrm{X}=$ Menyatakan nilai kriteria

$\mathrm{W}=$ Menyatakan bobot kriteria

$\mathrm{I}=$ Menyatakan alternatif

$\mathrm{J}=$ Menyatakan kriteria

$\mathrm{N}=$ Menyatakan banyaknya kriteria

* = Menyatakan banyaknya kriteria yang telah dinilai pada vector $S$

Adapun perpangkatan vector bernilai positif untuk atrbiut keuntungan dan bernilai negatif untuk atribut biaya. Menggunakan metode VIKOR

1. Normalisasi matrik dengan cara nilai terbaik dalam satu kriteria dikurangi dengan nilai data sampel i kriteria j , lalu dibagi dengan nilai terbaik dalam suatu kriteria dikurangi dengan nilai terjelek dalam satu kriteria.(Kusuma \& Ginting, 2020)

Dimana:

$$
\mathrm{R}_{\mathrm{ij}}=\frac{X_{j-X_{i j}}^{+}}{X_{j}^{+}-X_{j}^{-}}(4)
$$

$\mathrm{R}_{\mathrm{ij}}=$ nilai normalisasi sampel $\mathrm{i}$ kriteria $\mathrm{j}$

$X_{i j}=$ nilai data sampel $\mathrm{i}$ kriteria $\mathrm{j}$

$\mathrm{X}_{\mathrm{j}^{+}}=$nilai terbaik dalam satu kriteria

$\mathrm{X}_{\mathrm{j}^{-}}=$nilai terjelek dalam satu kriteria

2. Menghitung nilai utility $(S)$ dan regret measure $(R)$. Mengitung utility measure dengan cara mejumlah hasil dari perkalian bobot dengan hasil matrik, menghitung regret measure dengan cara mencari nilai maksimal dari perkalian bobot dengan hasil normalisasi. (Kusuma \& Ginting, 2020)

$$
\begin{gathered}
S_{i}=\sum_{j}^{n}=1 W_{j}\left(\frac{x_{j}^{+}-x_{i j}}{x_{j}^{+}-x_{j}^{-}}\right) \\
\operatorname{Dan} \\
R_{i}=\operatorname{Maxj}\left[W_{j}\left(\frac{x_{j}^{+}-x_{i j}}{x_{j}^{+}-x_{j}^{-}}\right)\right]
\end{gathered}
$$

Dimana :

$\mathrm{S}_{\mathrm{i}}=$ Nilai Utility Measure

$\mathrm{R}_{\mathrm{i}}=$ Nilai Regret Measure

$\mathrm{W}_{\mathrm{j}}=$ Bobot kriteria

$\mathrm{i}=$ alternatif

$\mathrm{j}=$ kriteria

3. Menghitung indeks VIKOR dengan cara nilai $S$ dikurangi $S^{-}$lalu dibagi dengan nila $S^{+}$ dikurangi dengan nilai $S^{-}$dan dikali $v$ dan dijumlahkan dengan nilai $R$ dikurangi nilai $R^{-}$lalu dibagi nilai $\mathrm{R}^{+}$dikurangi nilai $\mathrm{R}^{-}$dan dikali dengan 1 dikurangi V.(Kusuma \& Ginting, 2020)

$$
Q_{i}=v\left[\frac{S_{i}-S^{-}}{S^{+}-S_{-}}\right]+(1-v)\left[\frac{R_{i}-R^{+}}{R^{+}-R^{-}}\right](7)
$$

Dimana :

$\mathrm{Q}_{\mathrm{i}}=$ Nilai index VIKOR

$\mathrm{S}^{+}=$Nilai Utility Measure Terbesar

$\mathrm{S}^{-}=$Nilai Utility Measure terkecil

$\mathrm{R}^{+}=$Nilai Regret Measure Terbesar

$\mathrm{R}^{-}=$Nilai Regret Measure Terkecil

$\mathrm{V}=0,5$ 
4. Melakukan pemeringkatan nilai VIKOR $\left(Q_{i}\right)$. Pemeringkatan terhadap nilai $Q_{i}$ dilakukan berdasarkan nilai terbesar hingga nilai yang terkecil (ascending order), dengan nilai terkecil merupakan kandidat terbaik. Sehingga akan diperoleh tiga buah daftar/ versi pemeringkatan. Mengajukan solusi kompromi berdasarkan pemenuhan kondisi C1 dan C2. Solusi kompromi berupa alternatif (a') diajukan ketika kodisi C1 dan C2 terpenuhi dimana alternative a' merupakan alternatif yang menempati peringkat yang pertama dalam pemeringkatan nilai $\operatorname{VIKOR}\left(Q_{i}\right)$. (Imandasari \& Windarto, 2018)

\section{HASIL DAN PEMBAHASAN}

\section{Kriteria dan Bobot}

Dalam penelitian ini ada bobot dan kriteria yang dibutuhkan untuk menentukan siswa berprestasi pada Madrasah Ibtidaiyah Jamiatul Gulami Tangerang. Adapun Kriterianya adalah :

Tabel 1. Nama Siswa

\begin{tabular}{|l|l|l|l|l|l|l|}
\hline \multirow{2}{*}{ Kode } & \multirow{2}{*}{ Nama Alternatif } & \multicolumn{3}{|l|}{ Nilai } \\
\cline { 3 - 7 } & & C1 & C2 & C3 & C4 & C5 \\
\hline A1 & Amelia Putri & 87 & 80 & 70 & 75 & 65 \\
\hline A2 & Bagas Saputra & 85 & 78 & 80 & 70 & 60 \\
\hline A3 & Dimas Ramadhan & 75 & 85 & 75 & 64 & 75 \\
\hline A4 & Fajar Santoso & 80 & 75 & 80 & 78 & 85 \\
\hline A5 & Eka Yulia & 73 & 75 & 60 & 63 & 75 \\
\hline
\end{tabular}

Sumber : Penelitian (2020)

Tabel 1 berisi tentang data siswa dan nilai yang diproses menggunakan metode yang akan dilakukan oleh kami.

Tabel 2. Kriteria

\begin{tabular}{|l|l|}
\hline \multicolumn{1}{|c|}{ Kriteria } & \multicolumn{1}{c|}{ Keterangan } \\
\hline C1 & Nilai Rata-rata \\
\hline C2 & Kedisiplinan \\
\hline C3 & Absensi \\
\hline C4 & Ekstrakulikuler \\
\hline C5 & Non Akademik \\
\hline
\end{tabular}

Sumber : Penelitian (2020)

Tabel 2 mendefinisikan kriteri-kriteria yang akan dijadikan sebagai tolak ukur penyelasaian masalah.

Tabel 3. Nilai Bobot

\begin{tabular}{|l|l|l|}
\hline Kriteria & Range & Bobot \\
\hline C1 & Sangat Baik & 5 \\
\hline C2 & Baik & 4 \\
\hline C3 & Cukup & 3 \\
\hline C4 & Rendah & 2 \\
\hline C5 & Sangat Rendah & 1 \\
\hline
\end{tabular}

Sumber : Penelitian (2020)

Tabel 3 berisi nilai bobot untuk dijadikan acuan dalam perhitungan data

Tabel 4. Nilai Rata - rata Pada Kriteria

\begin{tabular}{|l|l|l|}
\hline Kriteria & Bobot & Nilai \\
\hline $81-100$ & Sangat Baik & 5 \\
\hline $61-80$ & Baik & 4 \\
\hline $41-60$ & Cukup & 3 \\
\hline $21-40$ & Rendah & 2 \\
\hline $0-20$ & Sangat Rendah & 1 \\
\hline
\end{tabular}


IJSE - Indonesian Journal on Software Engineering, Vol.6, No.2, Desember 2020, 270-279

Sumber : Penelitian (2020)

Tabel 4 berisi tentang nilai rata - rata pada setiap kriteria yang akan untuk dijadikan data pengolahan.

2. Perhitungan Metode Vikor

a. Membuat matrik keputusan dengan alternatif dan membuat max dan min, sebagai berikut :

\begin{tabular}{|l|c|c|c|c|l|} 
Tabel 9. Max dan Min \\
\hline Alternatif & C1 & C2 & C3 & C4 & C5 \\
\hline A1 & 87 & 80 & 70 & 75 & 65 \\
\hline A2 & 85 & 78 & 80 & 70 & 60 \\
\hline A3 & 75 & 85 & 75 & 64 & 75 \\
\hline A4 & 80 & 75 & 80 & 78 & 85 \\
\hline A5 & 73 & 75 & 60 & 63 & 75 \\
\hline Max & 87 & 85 & 80 & 78 & 85 \\
\hline Min & 73 & 75 & 60 & 63 & 60 \\
\hline
\end{tabular}

Sumber : Penelitian (2020)

Pada table ini langkah pertama mencari max dan min pada data tersebut pada metode Vikor.

b. Setelah mendapatkan max dan min selanjutnya akan menghitung matrik normalisasi dengan rumus

$$
\begin{array}{ll}
\mathrm{R}_{\mathrm{ij}}=\frac{X_{j-X_{i j}}^{+}}{X_{j}^{+}-X_{j}^{-}}(4) & \mathrm{R}_{21}=\frac{85-80}{85-75}=0,5 \\
\mathrm{R}_{11}=\frac{87-87}{87-73}=0 & \mathrm{R}_{22}=\frac{85-78}{85-75}=0,7 \\
\mathrm{R}_{12}=\frac{87-85}{87-73}=0,1428 & \mathrm{R}_{23}=\frac{85-85}{85-75}=0 \\
\mathrm{R}_{13}=\frac{87-75}{87-73}=0,8571 & \mathrm{R}_{24}=\frac{85-75}{85-75}=1 \\
\mathrm{R}_{14}=\frac{87-80}{87-73}=0,5 & \mathrm{R}_{25}=\frac{85-75}{85-75}=1 \\
\mathrm{R}_{15}=\frac{87-73}{87-73}=1 & \mathrm{R}_{41}=\frac{78-75}{78-63}=0,2 \\
\mathrm{R}_{31}=\frac{80-70}{80-60}=0,5 & \mathrm{R}_{42}=\frac{78-70}{78-63}=0,5333 \\
\mathrm{R}_{32}=\frac{80-80}{80-60}=0 & \mathrm{R}_{43}=\frac{78-64}{78-63}=0,9333 \\
\mathrm{R}_{33}=\frac{80-75}{80-60}=0,25 & \mathrm{R}_{44}=\frac{78-78}{78-63}=0,5 \\
\mathrm{R}_{34}=\frac{80-80}{80-60}=0 & \mathrm{R}_{45}=\frac{78-63}{78-63}=1 \\
\mathrm{R}_{35}=\frac{80-60}{80-60}=1 & \mathrm{R}_{54}=\frac{85-85}{85-60}=0 \\
\mathrm{R}_{51}=\frac{85-65}{85-60}=0,8 & \mathrm{R}_{55}=\frac{85-75}{85-60}=0,4 \\
\mathrm{R}_{52}=\frac{85-60}{85-60}=1 & \\
\mathrm{R}_{53}=\frac{85-75}{85-60}=0,4 &
\end{array}
$$


Bobot $(w): 5,4,3,2,1$

$\left(\begin{array}{lllll}0 & 0,5 & 0,5 & 0,2 & 0,8 \\ 0,1428 & 0,7 & 0 & 0,5333 & 1 \\ 0,8571 & 0 & 0,25 & 0,9333 & 0,4 \\ 0,5 & 1 & 0 & 0,5 & 0 \\ 1 & 1 & 1 & 1 & 0,4\end{array}\right)$

c. Langkah selanjutnya menghitung perkalian matrik Nij dengan $\mathrm{W}_{\mathrm{ij}}$ pada setiap kolom

$\left.\begin{array}{lllll}2 & 1,5 & 0,4 & \multicolumn{3}{c}{0,8} \\ 0,714 & 2,8 & 0 & 1,0666 & 1 \\ 4,2855 & 0 & 0,75 & 1,8666 & 0,4 \\ 2,5 & 4 & 0 & 1 & 0 \\ 5 & 4 & 3 & 2 & 0,4\end{array}\right]$

d. Langkah berikutnya menghitung utility measure dari setiap alternatif menggunakan persamaan dengan rumus (6)

$\mathrm{R}^{1}=0 ; 2 ; 1,5 ; 0,4 ; 0,8=2$

$\mathrm{R}^{2}=0,714 ; 2,8 ; 0 ; 1,0666 ; 1=2,8$

$\mathrm{R}^{3}=4,2855 ; 0 ; 0,75 ; 1,8666 ; 0,4=4,2855$

$\mathrm{R}^{4}=2,5 ; 4 ; 0 ; 1 ; 0=4$

$\mathrm{R}^{5}=5 ; 4 ; 3 ; 2 ; 0,4=5$

e. Kemudian dilakukan penjumlahan untuk mendapatkan hasil $S_{i}$ dengan mengguakan rumus (5)

$S^{1}=0+2+1,5+0,4+0,8=4,7$

$\mathrm{S}^{2}=0,714+2,8+0+1,0666+1=5,5806$

$S^{3}=4,2855+0+0,75+1,8666+0,4=7,3021$

$S^{4}=1+2,1332+2,7999+1+1=7,9331$

$S^{5}=5+4+3+2+0,4=14,4$

f. Berikutnya menentukan nilai $\mathrm{S}^{+}, \mathrm{S}^{-}, \mathrm{R}^{+}$, dan $\mathrm{R}^{-}$dimana $\mathrm{S}^{-}$dan $\mathrm{R}^{-}$merupakan nilai terendah

$\mathrm{S}^{+}=14,4$

$\mathrm{R}^{+}=5$

$S^{-}=4,7$

$\mathrm{R}^{-}=2$

g. Setelah mendapatkan hasil $\mathrm{S}^{+}, \mathrm{S}^{-}, \mathrm{R}^{+}$, dan $\mathrm{R}^{-}$, langkah selanjutnya adalah menghitung indeks VIKOR dengan rumus (7)

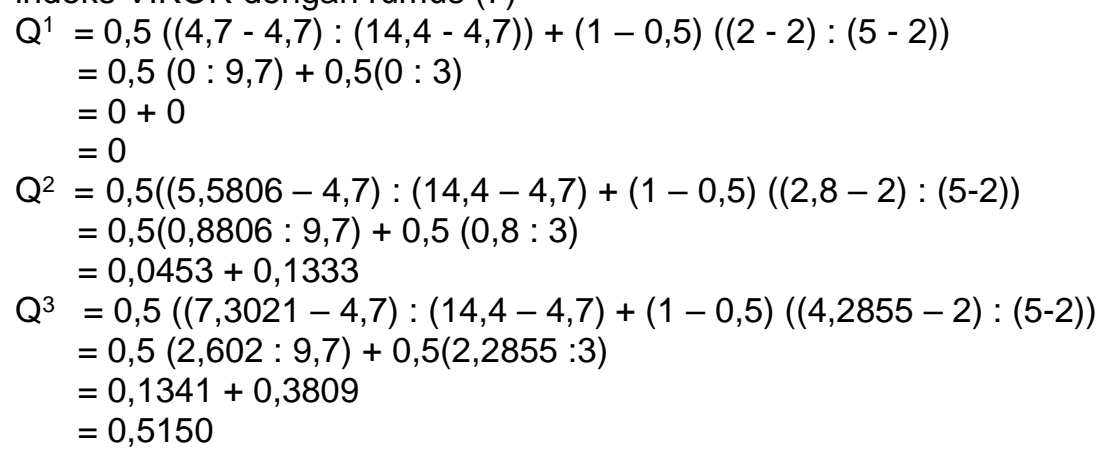






Tabel 10 Hasil Metode VIKOR

\begin{tabular}{|c|c|c|c|c|c|c|c|c|c|}
\hline Alternatif & C1 & $\mathrm{C} 2$ & $\mathrm{C} 3$ & $\mathrm{C} 4$ & $\mathrm{C} 5$ & $\mathrm{Si}$ & $\mathrm{Ri}$ & Qi & Rank \\
\hline $\mathrm{A} 1$ & 0,0000 & 0,5000 & 0,5000 & 0,2000 & 0,8000 & 4,7000 & 2,0000 & 0,0000 & 5 \\
\hline A2 & 0,1429 & 0,7000 & 0,0000 & 0,5333 & 1,0000 & 5,5810 & 2,8000 & 0,1787 & 4 \\
\hline A3 & 0,8571 & 0,0000 & 0,2500 & 0,9333 & 0,4000 & 7,3024 & 4,2857 & 0,5151 & 2 \\
\hline A4 & 0,5000 & 1,0000 & 0,0000 & 0,0000 & 0,0000 & 6,5000 & 4,0000 & 0,4261 & 3 \\
\hline A5 & 1,0000 & 1,0000 & 1,0000 & 1,0000 & 0,4000 & 14,4000 & 5,0000 & 1,0000 & 1 \\
\hline \multicolumn{6}{|c|}{ S- } & 4,7000 & 2,0000 & & \\
\hline \multicolumn{6}{|c|}{$\mathrm{S}^{*}$} & 14,4000 & 5,0000 & & \\
\hline
\end{tabular}

Sumber : Penelitian (2020)

h. Hasil Metode VIKOR

Setelah melakukan perhitungan data dengan menggunakan metode vikor, maka didapatkan hasil A5 sebagai siswa berprestasi

\section{Perhitungan Metode WP}

Tabel 11. Alternatif kriteria

\begin{tabular}{|c|l|c|}
\hline Kriteria & \multicolumn{1}{|c|}{ Keterangan } & NilaiBobot \\
\hline C1 & Nilai Rata-rata & 5 \\
\hline C2 & Kedisiplinan & 4 \\
\hline C3 & Absensi & 3 \\
\hline C4 & Ekstrakulikuler & 2 \\
\hline C5 & Non Akademik & 1 \\
\hline \multicolumn{2}{|c|}{ Total } & 15 \\
\hline
\end{tabular}

Sumber : Penelitian (2020)

Pada tabel diatas melakukan perhitungan menggunakan metode Weight Product

a. Melakukan normalisasi bobot menggunakan rumus (1)

$$
\begin{aligned}
& W 1=\frac{5}{5+4+3+2+1}=0,333333 \\
& W 2=\frac{4}{5+4+3+2+1}=0,266667 \\
& W 3=\frac{3}{5+4+3+2+1}=0,2 \\
& W 4=\frac{2}{5+4+3+2+1}=0,133333 \\
& W 5=\frac{1}{5+4+3+2+1}=0,066667
\end{aligned}
$$

b. Menghitung $x$ nilai vektor $S$ menggunakan rumus (2)

$$
\begin{aligned}
& \mathrm{S} 1=5^{\wedge} 0,333333 \times\left(4^{\wedge} 0,266667\right) \times\left(4^{\wedge} 0,2\right) \times\left(4^{\wedge} 0,133333\right) \times\left(4^{\wedge} 0,066667\right) \\
&=1,709975 \times 1,447269 \times 1,319507 \times 1,203024 \times 1,096825
\end{aligned}
$$




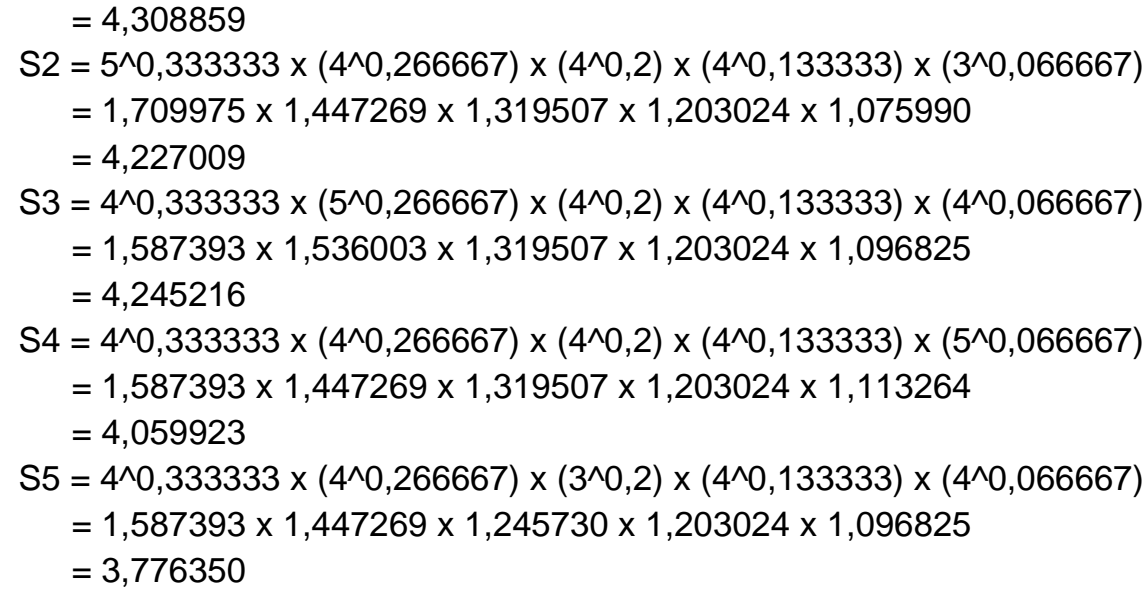

c. Selanjutnya menghitung nilai vektor $\mathrm{V}$ menggunakan rumus (3)

$\mathrm{V} 1=\frac{4,308859}{4,308859+4,227009+4,245216+4,059923+3,776350}=0,208419$

$V 2=\frac{4,227009}{4,308859+4,227009+4,245216+4,059923+3,776350}=0,204460$

$V 3=\frac{4,245216}{4,308859+4,227009+4,245216+4,059923+3,776350}=0,205341$

$\mathrm{V} 4=\frac{4,059923}{4,308859+4,227009+4,245216+4,059923+3,776350}=0,196378$

$V 5=\frac{3,832923}{4,308859+4,227009+4,245216+4,059923+3,776350}=0,185398$

d. Ranking dari metode WP

Tabel 12. Ranking

\begin{tabular}{|c|c|c|c|}
\hline Kode & NamaAlternatif & Nilai & Rank \\
\hline A1 & Amelia Putri & 0,20899157 & 1 \\
\hline A2 & Bagas Saputra & 0,20502156 & 3 \\
\hline A3 & Dimas Ramadhan & 0,20590558 & 2 \\
\hline A4 & Fajar Santoso & 0,19691831 & 4 \\
\hline A5 & EkaYulia & 0,18316298 & 5 \\
\hline
\end{tabular}

Sumber : Penelitian (2020)

Tabel diatas adalah hasil prangkingan yang di dapat oleh metode Weight Product

e. Hasil dari metode Weight Product

Setelah melakukan perhitungan data dengan menggunakan metode wp, maka didapatkan hasil A1 sebagai siswa berprestasi

\section{Perbandingan Hasil dari Metode VIKOR dan WP}

Berdasarkan Metode Vikor dan WP maka akan di peroleh hasi komparasi perangkingan dari kedua metode tersebut pada tabel 13

Tabel 13. Hasil Komparasi

\begin{tabular}{|c|c|c|c|c|c|}
\hline \multicolumn{2}{|c|}{ Metode Vikor } & \multicolumn{4}{c|}{ Metode WP } \\
\hline Alternatif & $\begin{array}{c}\text { Nilai } \\
\text { Total }\end{array}$ & Rank & Alternatif & $\begin{array}{c}\text { Nilai } \\
\text { Total }\end{array}$ & Rank \\
\hline A1 & 0.00 & 5 & A1 & 0.104 & 1 \\
\hline A2 & 0.18 & 4 & A2 & 0.078 & 3 \\
\hline A3 & 0.52 & 2 & A3 & 0.103 & 2 \\
\hline
\end{tabular}




\begin{tabular}{|l|l|l|l|l|l|} 
A4 & 0.43 & 3 & A4 & 0.121 & 4 \\
\hline A5 & 1.00 & 1 & A5 & 0.091 & 5 \\
\hline
\end{tabular}

Sumber : Penelitian (2020)

Pada tabel diatas terdapat hasil dari perbandingan metode VIKOR dan WP

\section{E. KESIMPULAN}

Hasil dari perbandingan metode VIKOR dan WP didapatkan hasil pada metode VIKOR Kode (A5) dengan nilai 1.00 Eka Yulia ditetapkan sebagai siswa berprestasi sedangkan bedasarkan metode WP siswa yang berprestasi ditunjukan kepada A1 atas nama Amelia Putri dengan nilai 0.104. dan disimpulkan bahwa terdapat perbedaan diantara kedua metode tersebut. Berdasarkan dari hasil penelitian yang diperoleh metode yang lebih efektif dan efisien untuk digunakan dalam penelitian ini yaitu metode Weight Product (WP). Dikarenakan metode wp sangat akurat dalam perhitungannya. Untuk penelitian kedepan, sisten ini masih bisa dikembangkan lagi dengan cara menambah bobot kriteria - kriteria yang baik, atau dengan metode - metode yang lain. Diharapkan bagi pihak guru untuk menggunakan metoe WP dalam penentuan siswa berprestasi, karena dari penelitian yang telah dilakukan hasil metode WP lebih efektif dan efisien.

\section{F. REFRENSI}

Ayu Septiana Sari, Jumadil Nangi, R. R. (2016). Penerapan Metode Promethee Dalam Sistem Penunjang Keputusan Penentuan Penerima Beasiswa Bidik Misi Universitas Halu Oleo. SemanTIK, 2(2), 229-236.

Fauzi, M., Ridwan, M., \& Khalid, K. (2020). Kombinasi Metode AHP dan VIKOR Untuk Pemilihan Santri Berprestasi. Matics, 12(1), 28. https://doi.org/10.18860/mat.v12i1.8270

Imandasari, T., \& Windarto, A. P. (2018). Penerapan Metode VIKOR Pada Pemilihan Popok Bayi Berdasarkan Jenis Kulit. Seminar Nasional Sains \& Teknologi Informasi (SENSASI), 215220.

Janosik, S. M. (2005). Pengembangan Aplikasi Pemilihan Smartphone Android Menggunakan Metode Weighted Product Berbasis Android. Naspa Journal, 42(4), 1. https://doi.org/10.1017/CBO9781107415324.004

Kusuma, A., \& Ginting, G. (2020). Sistem Pendukung Keputusan Pemilihan Apoteker Terbaik Pada PT. Kimia Farma (Persero) Tbk Medan Menerapkan Metode Vikor. Jurnal Sistem Komputer Dan Informatika (JSON), 1(3), 252. https://doi.org/10.30865/json.v1i3.2163

Limbong, T., \& Dkk. (2020). Sistem Pendukung Keputusan: Metode \& Implementasi (A. Rikki (ed.)). Yayasan Kita Menulis. https://books.google.co.id/books?id=t5PYDwAAQBAJ\&pg=PR7\&dq=pengertian+metode+ vikor\&hl=en\&sa=X\&ved=2ahUKEwiQ7omSy7LrAhWi7HMBHdvOCzQQ6AEwAHoECAUQ $\mathrm{Ag}$

Muslihudin, M., \& Rahayu, D. (2018). Sistem Pendukung Keputusan Siswa Berprestasi. 9, 1-6.

Noviyanti, A., \& Rizki, R. (2019). Perbandingan Siswa Les Dan Tidak Les Terhadap Prestasi. BIOnatural, $6(1)$,

$102-114$. https://ejournal.stkipbbm.ac.id/index.php/bio/article/viewFile/335/288

Suryani, \& Hendryadi. (2015). Metode Riset Kuantitatif teori dan aplikasi pada penilitian bidang manajemen dan ekonomi islam (kencana). PRENADAMEDIA GROUP. https://books.google.co.id/books?id=YHA-

DwAAQBAJ\&printsec=frontcover\&hl=id\&source=gbs_ge_summary_r\&cad=0\#v=onepage \& $q \& f=f a l s e$

Suryeni, E., Dan, Y. H. A., \& Nurfitria, Y. (2015). Sistem Pendukung Keputusan Kelayakan Penerimaan Bantuan Beras Miskin Dengan Metode Weighted Product Di Kelurahan Karikil Kecamatan Mangkubumi Kota Tasikmalaya. Konferensi Nasional Sistem \& Informatika 2015, 345-350.

Wijaya, I. (2019). Penerapan Metode AHP dan VIKOR Dalam Pemilihan Karyawan Berprestasi. A, 301-309.

Yusnaeni, W. (2018). ISSN : 2461-0690 1. Perbaikan Nilai Bobot (W) ISSN : 2461-0690. 4(2). 